\title{
Distribution of the stone marten Martes foina (Carnivora, Mustelidae) in the European part of Russia
}

\author{
Alexei V. Abramov, Sergei V. Kruskop \& Andrey A. Lissovsky \\ ABSTRACT. The stone marten Martes foina (Carnivora, Mustelidae) is widely distributed in continental \\ Europe from the Mediterranean to the Baltic Sea, and from Spain to Volga River. North-eastern border of \\ the species distribution in Eastern Europe is poorly known. Its presence in Moscow Province was confirmed \\ by the specimen found in the vicinity of Kupavna. The recent records of $M$. foina from the European part of \\ Russia are discussing, fragmentariness and heterogeneity of these data is demonstrating.
}

KEY WORDS: Martes foina, Mustelidae, distribution, Moscow Province, European Russia.

AlexeiV. Abramov [aav@aa2510.spb.edu], Zoological Institute, Russian Academy of Sciences, Universitetskaya nab. 1, Saint Petersburg 199034, Russia; SergeiV. Kruskop [kruskop@zmmu.msu.ru], Zoological Museum, Moscow State University, ul. Bolshaya Nikitskaya 6, Moscow 125009, Russia; Andrey A. Lissovsky [andlis@zmmu.msu.ru], Zoological Museum, Moscow State University, ul. Bolshaya Nikitskaya 6, Moscow 125009, Russia.

\section{Распространение каменной куницы Martes foina (Carnivora, Mustelidae) в Европейской части России}

\section{А.В. Абрамов, С.В. Крускоп, А.А. Лисовский}

РЕЗЮМЕ. Каменная куница широко распространена в континентальной Европе от Средиземного до Балтийского моря и от Испании до берегов Волги. Северо-восточная граница вида в Восточной Европе изучена недостаточно. Обитание каменной куницы в Московской области подтверждено находкой в окрестностях Купавны. В работе представлены современные данные о находках M. foina в европейской части России, продемонстрирована фрагментарность и неоднородность этих данных.

КЛЮЧЕВЫЕ СЛОВА: Martes foina, Mustelidae, распространение, Московская область, Европейская часть России.

The stone marten, or beech marten, Martes foina (Erxleben, 1777) is widely distributed in Palaearctic: from Spain to Central Europe and south part of Eastern Europe, also on islands of Corfu, Crete and Rhodes; through Caucasus Mountains, mountainous regions of Iran and Middle Asia to the Altai Mountains, Mongolia, Himalayas and adjacent parts of China. This is a common mustelid in continental Europe, which distribution area spread from Mediterranean to Baltic Sea and from Portugal to Volga River. However, its northern border in Eastern Europe still stays very poorly known (Fig. 1). Beech marten recorded in Baltic States (Latvia, Lithuania, and Estonia), in western and southern region of Belarus, and Ukraine.

In Russia the species distribution is represented by three fragments not connected with each other. One of them is located in Siberia covering southern part of the Altai Mountains; second one covers the Northern Caucasus and the third fragment is situated in the central part of European Russia. The distribution of the stone marten in the European Russia is highly controversial and in a great extant is based on the anecdotal evidences from trappers and foresters.
Stone marten was reported for the Moscow Province by several authors (Ognev, 1931; Novikov, 1956); however most of these records look doubtful. Ognev (1931) reported about trapping of three specimens of M. foina in Shchurovo near Kolomna $\left(55^{\circ} 03^{\prime} \mathrm{N}\right.$, $\left.38^{\circ} 49^{\prime} \mathrm{E}\right)$. This record together with some personal communications from trappers gave him ability to include stone marten into the fauna of Moscow Province. However, Heptner (Heptner et al., 1967) reviewing all the available records of $M$. foina from the European Russia, came to the conclusion that all findings in the Moscow Province are invalid because none of them were confirmed by any collection specimens. Meantime, in 1936 the stone marten was introduced into eastern part of Ryazan Province (Lavrov, 1946; Nazarov, 1957; Grakov, 2001). Fifty-four specimens were released on the right bank of Oka River not far from mouth of Moksha River in the Laptevsky Forestry of Oksko-Kasimovsky Hunting Area (ca. $54^{\circ} 57^{\prime} \mathrm{N}, 41^{\circ}$ $22^{\prime} \mathrm{E}$ ). In 1946-1952 stone martens were trapped near Kasimov, Spassk, and Solodtcha (Nazarov, 1957), about $70 \mathrm{~km}$ from present border of Moscow Province. Heptner (Heptner et al., 1967) supposed that small popula- 


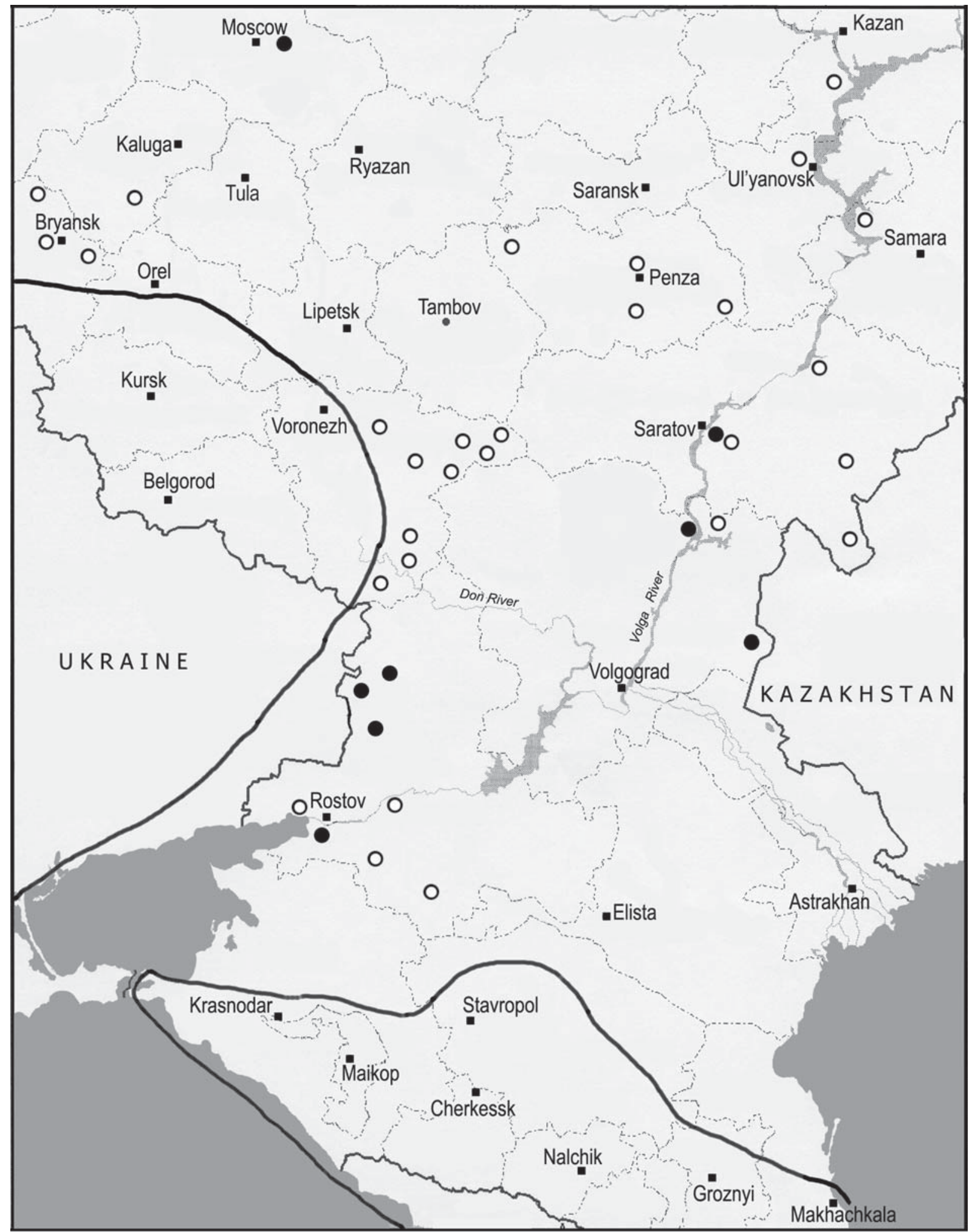

Figure 1. Distribution of Martes foina in European part of Russia. Solid line is the border of $M$. foina distribution according to Heptner et al. (1967). Recent museum records are shown in black circles, literature data are in open circles. 
tion of stone martens could survive in the Ryazan Province, from where single animals were able to reach Moscow and Vladimir provinces. However there were also no any evidences of this suggestion for many years. Grakov (2001: 110) believed that introduced population of stone marten in Ryazan Province completely disappeared and all recent records from this area are results of modern expanding of $M$. foina.

On 20 June 2003 the carcass of stone marten was occasionally found near the town of Kupavna, less than $20 \mathrm{~km}$ east from Moscow $\left(55^{\circ} 45^{\prime} \mathrm{N}, 38^{\circ} 07^{\prime} \mathrm{E}\right)$ by second and third authors. The adult animal, probably killed by some vehicle, was found on the roadside. The full skeleton and skull with deeply worn teeth are stored in the Zoological Museum of Moscow State University (ZMMU S-175493). This individual may be a distant occasional migrant, but there is a small possibility, that stone marten inhabit Moscow Province, but the density of population is very low. Necessary to take into consideration that evidences for this species in the form of skins or skulls are very rare even from many provinces where $M$. foina is thought to be a resident without doubts (see below). In any case the solution of this problem should be able only with new records and observations.

According to Heptner (in Heptner et al., 1967) the north border of $M$. foina distribution in the European Russia is going more than $400 \mathrm{~km}$ south from Moscow crossing south-western part of Bryansk Province where this species was reported for Surazh, Pochep, Trubchevsk, and Pogar. The species was recorded for the Novosil' of Orel Province (see also Ognev, 1931). Eastward the stone marten recorded for Bobrov of Voronezh Province. Close to the central provinces of European Russia stone marten is known from Lugansk District of Ukraine and Gomel Province of Belarus (see Heptner et al., 1967, Fig. 219).

In 1960-1970 the distribution of stone marten already covered most of Bryansk Province (Vatolin, 1979). Since $1970^{\text {th }} M$. foina was recorded in many districts of Voronezh Province close to the borders of Saratov, Volgograd and Tambov provinces (Ryabov \& Sokolov, 1988). Northward from distribution border sensu Heptner (Heptner et al., 1967) stone marten was recently reported for Kaluga Province (Kaluzhskiye Zaseki Nature Reserve; $c a .53^{\circ} 58^{\prime} \mathrm{N}, 35^{\circ} 32^{\prime} \mathrm{E}$ ) (Alekseev et al., 2002). Unfortunately this record was not supported by collection material.

There are comparatively more records of $M$. foina from the Middle and Lower Povolzh'ye (=Volga River Area). According to Iljin et al. (1996) the stone marten now is widely distributed in the Penza Province and was reported for southern part of Ul'yanovsk Province. However the only published record of $M$. foina in the latter province is based on the footprints, observed in the town of Ul'yanovsk in the beginning of $1990^{\text {th }}$ (Borodin, 2001). In winter 1987-1988 the single stone marten was trapped in Tatarstan (Verkhneuslonsk District, Sviyaga Forestry), on the right bank of Volga
River (Popov \& Lukin, 1988). Garanin et al. (2000) also mentioned the trapping of stone marten in Kamskoe Ust'ye District of Tatarstan. Although some authors mentioned the stone marten for the Zhiguli Mountains in Samara Province (Popov \& Lukin, 1988), there were no cogent arguments for its presence in Samarskaya Luka or Zhiguli (V. Vekhnik, pers.comm., 2004). The only actual evidence for Samara Province is the road-killed specimen of $M$. foina found in 2001 near Verkhnie Belozerki Village $\left(53^{\circ} 43^{\prime} \mathrm{N}, 49^{\circ} 13^{\prime} \mathrm{E}\right)$, on the left bank of Volga River (Borodin, 2001).

In Saratov Province the stone marten recorded for the valleys of left tributaries of Volga River - Eruslan, Bolshoi Uzen' (south of Aleksandrov Gay) and Bolshoi Irgiz rivers (Iljin et al., 1996). There are four specimens of $M$. foina from Engels District of Saratov Province in the collection of Zoological Institute Russian Academy of Sciences (Tab. 1), collected in $1980^{\text {th }}$.

Iljin et al. (1996) believe the eastern border of $M$. foina distribution in the European part of Russia lies on left bank of Volga River from Volga-Akhtuba Mezhdurechye (=interfluve) to the mouth of Eruslan River. The presence of stone marten in Volgograd Province is supported by two specimens (Tab. 1). First one was trapped in $30 \mathrm{~km}$ north-east of Kamyshin $\left(50^{\circ} 25^{\prime} \mathrm{N}\right.$, $45^{\circ} 49^{\prime} \mathrm{E}$ ) in 1996 . In the ZMMU collection there is the skin of $M$. foina collected near Elton Village in Volgograd Province $\left(49^{\circ} 10^{\prime} \mathrm{N}, 46^{\circ} 49^{\prime} \mathrm{E}\right)$ in 2003 .

The first published record of stone marten in Rostov Province was made near Zernograd $\left(46^{\circ} 51^{\prime} \mathrm{N}, 40^{\circ} 18^{\prime} \mathrm{E}\right)$ in the $1950^{\text {th }}$ (Minoranski, 1963). Abelentsev et al. (1973) mentioned few additional trappings of stone martens in Rostov Province. One was trapped in Nedvigovka Village, Myasnikovsky District in west part of the province in 1960; the second one was killed near Gigant Railway Station, Salsk District, and the third specimen was captured in the valley of Don River, Konstantinovsky District. Also there are nine specimens of $M$. foina from the western parts of Rostov Province in the collection of Zoological Institute Russian Academy of Sciences (ZIN O.35251-O.35259) which were trapped in 1985-1993. Probably the stone marten became more abundant in the given province since $1970^{\text {th }}$ (Abelentsev et al., 1973). If it is so, there is ability for connection between Central Russian and Caucasian parts of $M$. foina distribution area.

It is possible to see from our review that there are a very few confirmed records (collection specimens) of M. foina as from the distribution area in European Russia sensu Heptner et al. (1967), and also outside of these borders. Some interview data and sightings can be result of misidentification of the pine marten, Martes martes. Some specimens of pine marten have a very light throat spot and can be deciding as the stone marten. The correct identification should take into account skull characters and/or the whole set of external characters including shape and coloration of throat spot, relative length of tail and relative fur density of foot (see Baryshnikov, 2001). 
Table 1. Museum specimens of Martes foina from European part of Russia in the Zoological Institute Russian Academy of Sciences (ZIN) and Zoological Museum of Moscow State University (ZMMU).

\begin{tabular}{|c|c|c|c|c|c|}
\hline Localities & Material & Sex & Date & Collector & $\begin{array}{l}\text { Location held and } \\
\text { catalogue number }\end{array}$ \\
\hline Moscow Province, near Kupavna & skull, skeleton & & 20.VI.2003 & $\begin{array}{l}\text { S.V. Kruskop, } \\
\text { A.A. Lissovsky }\end{array}$ & ZMMU S-175493 \\
\hline \multirow{4}{*}{ Saratov Province, Engels District } & \multirow{4}{*}{ skulls } & male & 1987 & V.N. Moseikin & ZIN O.35552 \\
\hline & & & & & ZIN O.35553 \\
\hline & & & & & ZIN O.35554 \\
\hline & & & & & ZIN O.35555 \\
\hline $\begin{array}{l}\text { Volgograd Province, } 30 \mathrm{~km} \mathrm{NE} \text { of } \\
\text { Kamyshin, right bank of Volga River }\end{array}$ & skin, skull, skeleton & female & 13.VI.1996 & V.Yu. Iljin & $\begin{array}{l}\text { ZIN O.34644 (skull, } \\
\text { skeleton), ZIN } \\
\text { C.82619 (skin) }\end{array}$ \\
\hline Volgograd Province, Elton Village & skin & & II.2003 & V.A. Lopushkov & ZMMU S-175432 \\
\hline $\begin{array}{l}\text { Rostov Province, Verkhnedonsk District, } \\
\text { Konotop Forestry }\end{array}$ & skull & male & 29.XI.1988 & P. Ivliev & ZIN No.35251 \\
\hline \multirow{4}{*}{ Rostov Province, near Millerovo } & \multirow{4}{*}{ skulls } & \multirow{2}{*}{ male } & 25.XI.1985 & \multirow{4}{*}{ C.V. Topolyanets } & ZIN No.35252 \\
\hline & & & 25.X.1985 & & ZIN No.35253 \\
\hline & & \multirow{2}{*}{ female } & 3.X.1985 & & ZIN No.35254 \\
\hline & & & XII.1985 & & ZIN No.35259 \\
\hline \multirow{2}{*}{$\begin{array}{l}\text { Rostov Province, Kamensky District, } \\
\text { Starostanichnoe Hunting Area }\end{array}$} & \multirow{2}{*}{ skull } & \multirow{2}{*}{ male } & 9.I.1993 & \multirow{2}{*}{ V.I. Dedov } & ZIN No.35255 \\
\hline & & & I.1993 & & ZIN No.35256 \\
\hline $\begin{array}{l}\text { Rostov Province, near Rostov-na-Donu, } \\
\text { Zadon'e }\end{array}$ & skull & & XII.1992 & Pshenichnyi & ZIN No.35257 \\
\hline $\begin{array}{l}\text { Rostov Province, Tarasovsky District, } \\
\text { Mityakinskaya }\end{array}$ & skull & female & 11.XI.1989 & S.P. Ivanov & ZIN No.35258 \\
\hline
\end{tabular}

ACKNOWLEDGMENTS. We thank to Vladimir Vekhnik (Zhiguli Nature Reserve) for helpful information. Prof. Vladimir Iljin (Penza Pedagogical University) and Dr. Georgy Bakhtadze (Rostov State University) donated a many collection specimens for the Zoological Institute Russian Academy of Sciences from the European part of Russia. We thank to Dr. Alex Borissenko for their help in field work in Moscow Province. We are thankful to Dr. Dmitri Logunov (Manchester University) for improving the English.

\section{References}

Abelentsev V.I., Bakeev N.N. \& Nasimovich A.A. 1973. [The stone marten] // Nasimovich A.A. (ed.). Sable, Martens, Yellow-throated Marten. Moskva: Nauka. P.201-222 [in Russian].

Alekseev S.K., Galchenkov Yu.D., Kostyuhina O.S., Chervyakova O.G., Fedoseev S.V. \& Hernandez-Blanko J.A. 2002. [Mammals of the "Kaluzhskiye Zaseki" Nature Reserve and adjacent territories] // Izvestiya Kaluzhskogo Obshestva Izucheniya Prirody Mestnogo Kraya. Vol.5. P.124-143 [in Russian].

Baryshnikov G.F. 2001. [Order Carnivora] // Aristov A.A. \& Baranova G.I. (eds.). [Mammals of Russia and Adjacent Territories. Carnivores and Pinnipeds]. Sankt-Peterburg: Rossiiskaya Akademya nauk. P.11-425 [in Russian].
Borodin O.V. 2001. [New finding of the stone marten in the Srednee Povolzh'e] // Priroda Simbirskogo Povolzh'ya. No.2. P.168-169 [in Russian].

Garanin V.I., Egorov I.Ya \& Ryabova G.A. 2000. [Animal World of Eastern Zakam'ya (=south-east part of Tatarstan)]. Al'met'evsk: Kazanskii Gosudarstvennyi Universitet. 237 p. [in Russian]

Grakov N.N. 2001. [The pine marten and stone marten] // Grakov N.N. (ed.). Acclimatization and Biotechnique in the Management of Populations of the Game Animals]. Kirov: Rossiiskaya Akademya sel'skokhozyaistvennykh nauk. P.110-113 [in Russian].

Heptner V.G., Naumov N.P., Yurgenson P.B., Sludsky A.A., Chirkova A.F. \& Bannikov A.G. 1967. [Mammals of Soviet Union. Vol.2. Part 1. Sea Cows and Carnivora]. Moskva: Vysshaya Shkola. 1004 p. [in Russian]

Iljin V.Yu., Ermakov O.A. \& Lukyanov S.B. 1996. [New data on distribution of mammals in Povolzh'e and Volga-Ural River region] // Byulleten' Moskovskogo Obshchestva Ispytatelei Prirody, Otdel Biologicheskii. T.101. Vyp.2. P.30-37 [in Russian with English summary].

Lavrov N.P. 1946. [Acclimatization and Re-acclimatization of Fur Animals in USSR]. Moskva: Zagotizdat. 220 p. [in Russian]

Minoranskii V.A. 1963. [On the distribution of stone marten (Martes foina Erxl.) in Rostov Province] // Zoolo- 
gicheskii Zhurnal. T.42. Vyp.9. P.1423-1424 [in Russian].

Nazarov I. 1957. [The stone marten in Ryazan Province] // Okhota i Okhotnich'e Khozyaistvo. No.10. P.25 [in Russian].

Novikov G.A. 1956. [The Carnivorous Mammal of USSR Fauna]. Moskva-Leningrad: Izdatel'stvo Akademii nauk SSSR. 294 p. [in Russian]

Ognev S.I. 1931. [The Animals of the Eastern Europe and Northern Asia]. Vol.2. Moskva-Leningrad: Gosizdat. 776 p. [in Russian]
Popov V.A. \& Lukin A.V. 1988. [The Animals of Tataria. Vertebrates]. Kazan: Tatarskoe knizhnoe izdatel'stvo. 248 p. [in Russian]

Ryabov L. \& Sokolov M. 1988. [Stone marten and otter in the Voronezh Province] // Okhota i Okhotnich'e Khozyaistvo. No.11. P.14-16 [in Russian].

Vatolin B.A. 1979. [Distribution and biology of the stone marten in the Bryansk Province] // Sokolov V.E. (ed.). Ecological Basics of Conservation and Rational Use of Carnivore Mammals. Moskva: Nauka. P.303-305 [in Russian]. 